\title{
Frequency of the Val1016Ile mutation on the $k d r$ gene in Aedes aegypti (Diptera: Culicidae) in south Brazil
}

\author{
M.L. Collet ${ }^{1}$, C. Frizzo ${ }^{1}$, E. Orlandin ${ }^{1}$, L.D.P. Rona ${ }^{2}$, J.C. Nascimento ${ }^{3}$, \\ M.A.E. Montano ${ }^{1}$, G.A. Müller ${ }^{4}$ and G. Wagner ${ }^{1,5}$ \\ ${ }^{1}$ Universidade do Oeste de Santa Catarina, Campus Joaçaba, Joaçaba, \\ SC, Brasil \\ ${ }^{2}$ Departamento de Biologia Celular, Embriologia e Genética, \\ Universidade Federal de Santa Catarina, Trindade, Florianópolis, SC, Brasil \\ ${ }^{3}$ Divisão de Vigilância Epidemiológica de Santa Catarina, Florianópolis, \\ SC, Brasil \\ ${ }^{4}$ Instituto Federal de Educação, Ciência e Tecnologia Farroupilha, \\ Campus Panambi, Panambi, RS, Brasil \\ ${ }^{5}$ Departamento de Microbiologia, Imunologia e Parasitologia, \\ Universidade Federal de Santa Catarina, Florianópolis, SC, Brasil \\ Corresponding author: G. Wagner \\ E-mail: glauber.wagner@ufsc.br \\ Genet. Mol. Res. 15 (4): gmr15048940 \\ Received July 1, 2016 \\ Accepted August 9, 2016 \\ Published November 21, 2016 \\ DOI http://dx.doi.org/10.4238/gmr15048940
}

Copyright (C) 2016 The Authors. This is an open-access article distributed under the terms of the Creative Commons Attribution ShareAlike (CC BY-SA) 4.0 License.

\begin{abstract}
Recently, the number of Aedes aegypti foci has increased in west of Santa Catarina, south Brazil, which has increased concern regarding mosquito-borne disease outbreaks such as dengue fever, Zika virus, and chikungunya. Therefore, it is important to monitor genetic resistance to insecticides through "knockdown resistance". Homozygosity (Ile/Ile) at position 1016 in
\end{abstract}


the coding region of a voltage-dependent sodium channel gene $\left(N a_{v}\right)$ may induce resistance to pyrethroid insecticides. We evaluated the frequency of these alleles in $A$. aegypti in west Santa Catarina. In total, 349 specimens were obtained from the microregions of Joaçaba (31), Concórdia (35), Chapecó (154), and São Miguel do Oeste (129). We found that 109 individuals $(31.0 \%)$ were homozygous for $\mathrm{Val} / \mathrm{Val}, 102(29.0 \%)$ were heterozygous for $\mathrm{Val} / \mathrm{Ile}$, and 138 $(40.0 \%)$ were homozygous for Ile/Ile. The allele frequencies were similar for Val (0.455) and Ile (0.545). Joaçaba and Concórdia had the highest mutant allele frequencies ( 0.825 and 0.685 , respectively). Therefore, these populations should be monitored for increases in pyrethroid resistance. The São Miguel do Oeste and Chapecó populations had similar frequencies of Val and Ile and were not in Hardy-Weinberg equilibrium, suggesting that a selection pressure or other evolutionary force has occurred. In conclusion, the observed frequency of Ile/Ile homozygous individuals in the region studied requires attention, because the implementation of controls using pyrethroid may increase the frequency of the mutant allele through the selection of resistant populations.

Key words: Mechanism of resistance; Mosquito; kdr; Genetic diversity

\section{INTRODUCTION}

The Aedes aegypti mosquito is an important vector of arbovirus infections such as dengue fever, chikungunya, Venezuelan equine encephalitis, Mayaro, yellow fever, and Zika virus, and is abundant in urban areas. The proliferation of this insect is often related to the urbanization process, which allows the creation of peripheral zones with a poor basic sanitation infrastructure or improper waste disposal. Following rainfall, such waste can become a breeding ground for the mosquito (Marcondes and Ximenes, 2015).

In Brazil, the three main arbovirus infections related to this vector in terms of case number and severity are dengue fever, chikungunya, and more recently, the Zika virus (Marcondes and Ximenes, 2015). In 2015, approximately 20,500 suspected cases of chikungunya and 1.6 million probable dengue cases were registered, representing a record for this disease in the country (Honório et al., 2015). In April 2015, the autochthonous transmission of the Zika virus was confirmed, and up to April 2016, the transmission was confirmed in 22 Brazilian states with approximately 91,000 suspected cases (Brasil, 2016).

Arbovirus diseases have a large negative impact on Brazil's public health due to increased morbidity and mortality, which are dependent on the population profile (Lopes et al., 2014). Despite the recent development of a vaccine for three subtypes of dengue virus (DENV) (Villar et al., 2015), the control of the vector population is the preferred disease control method. Currently, this is performed using insecticides that are mainly from the organophosphate and pyrethroid classes (Macoris et al., 2014).

However, when insecticides are used to control $A$. aegypti, they select for resistant populations over time, making effective control of these disease vectors further difficult

Genetics and Molecular Research 15 (4): gmr15048940 
(Chediak et al., 2016). The ability of individuals of a particular species to tolerate higher insecticide dosages, which are often lethal to the majority of individuals, is a physiological phenomenon known as species resistance. Genetically, this phenomenon is characterized by an increase in allele frequencies in a population as a direct result of the selection effects caused by pesticides (Braga and Valle, 2007a).

Among the biological changes associated with insecticide resistance, increases in the insect's metabolic rate and changes in insecticide target sites are the most frequent. The latter occurs because of one or a series of mutations, and is known as "knockdown resistance" (kdr). One such effect in A. aegypti occurs through mutations in the coding region of a voltagedependent sodium channel gene $\left(N a_{v}\right)$, which directly affects the insect's nerve cells, leading to their failure to repolarize and subsequent death (Ishak et al., 2015).

Many medically important mosquito species, including Anopheles gambiae, Culex pipiens, Culex quinquefasciatus, and $A$. aegypti, have kdr mutations. Several punctual mutations are associated with this phenomenon, such as the L1014F polymorphism in $A$. gambiae (Martinez-Torres et al., 1998) and C. pipiens (Martinez-Torres et al., 1999), and the L1014S polymorphism in C. pipiens (Martinez-Torres et al., 1999).

Several mutations related to kdr have been described in $A$. aegypti, for example V1016I, I1011M (Batista, 2012), G923V, V952I, H961K, L982W, I1011M, I1011V (Brengues et al., 2003), V1011M, V1016I (Saavedra-Rodriguez et al., 2007), and V1016G (Rajatileka et al., 2008). The mutation in the first base of codon 1016 appears to be important for mosquito resistance due to its high frequency. This mutation is responsible for the change of one valine (Val) to isoleucine (Ile) (Val1016Ile) (Saavedra-Rodriguez et al., 2007). This resistant phenotype has been observed in Brazil (Brengues et al., 2003; Saavedra-Rodriguez et al., 2007; Piccoli, 2010; Batista, 2012).

In Santa Catarina State in the south of Brazil, a significant increase in the number of $A$. aegypti foci has been observed over the past decade (DIVE, 2015). However, no studies have been conducted on the frequency of kdr occurrence. Therefore, this study's objective was to evaluate the presence and frequency of Val and Ile polymorphisms at the 1016 position in the $N a_{v}$ coding region in $A$. aegypti populations in the west mesoregion of Santa Catarina.

\section{MATERIAL AND METHODS}

\section{Samples}

The study was performed using immature A. aegypti individuals obtained from November 2014 to May 2015 in the west mesoregion of Santa Catarina, which is divided into four microregions: Chapecó (30 municipalities), Concórdia (7 municipalities), Joaçaba (12 municipalities), and São Miguel do Oeste (16 municipalities) (Figure 1).

Overall, 349 specimens were analyzed. They were obtained using ovitraps that were maintained and monitored by the Health Departments of the municipalities, according to the Manual of Technical Standards of the National Health Foundation (FUNASA, 2001). The specimens were identified as $A$. aegypti by the Santa Catarina State Board of Epidemiological Vigilance (DIVE/SC), and larvae and pupae were sent to the Laboratory of Infectious and Parasite Diseases in Unoesc (Joaçaba) to determine the resistance genotype $(k d r)$.

Genetics and Molecular Research 15 (4): gmr15048940 


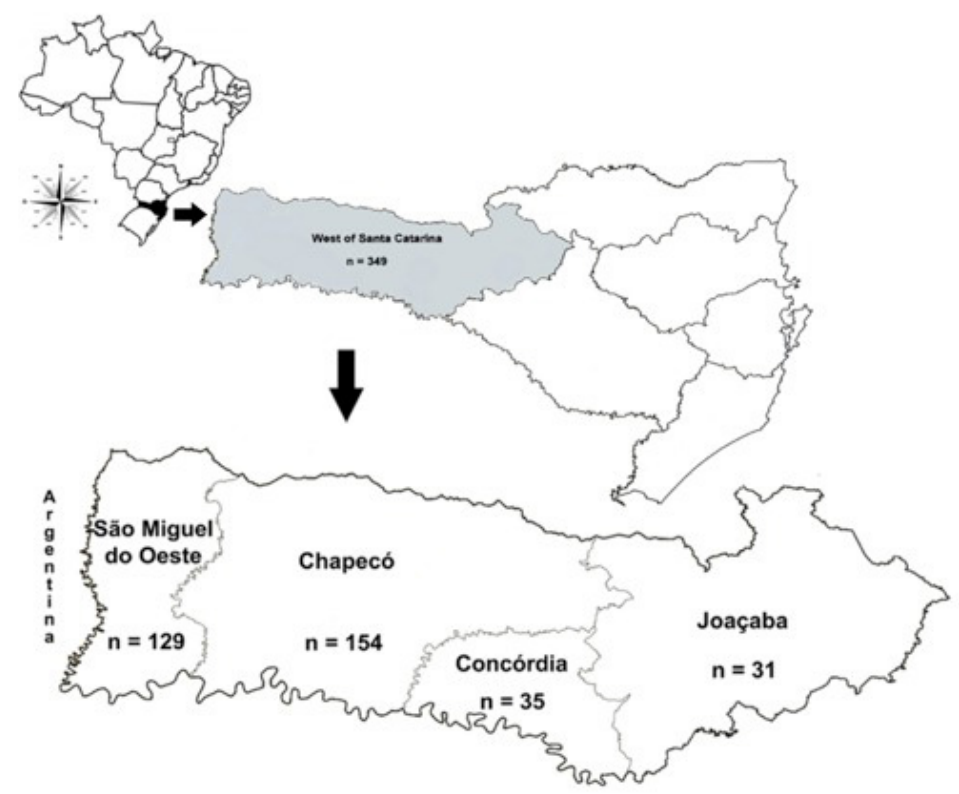

Figure 1. Map of the mesoregion of the west of Santa Catarina, Brazil, with the number of specimens (n) sampled in the meso- and microregions shown (São Miguel do Oeste, Chapecó, Concórdia, and Joaçaba).

\section{DNA extraction}

DNA was obtained using Chelex ${ }^{\circledR}$ (Chelating ion exchange resin) (SIGMA, Darmstadt, Germany), in which samples were macerated in $100 \mu \mathrm{L}$ sterilized ultrapure water and $100 \mu \mathrm{L}$ $1 \mathrm{X}$ phosphate-buffered saline (PBS), followed by centrifugation at 20,000 $\mathrm{g}$ for $2 \mathrm{~min}$. After discarding the supernatant, a solution was made by adding the precipitate to $100 \mu \mathrm{L} 1 \mathrm{X}$ PBS, followed by centrifugation at 20,000 $\mathrm{g}$ for $2 \mathrm{~min}$. Subsequently, the precipitate was transformed into a solution through shaking for $5 \mathrm{~s}$ to release the pellet, with $75 \mu \mathrm{L}$ sterilized ultrapure water and $25 \mu \mathrm{L}$ Chelex $^{\circledR} 20 \%$ solution. A small hole was then made in the tube surface, and the samples were incubated for $10 \mathrm{~min}$ at $90^{\circ} \mathrm{C}$. The samples were then centrifuged for $1 \mathrm{~min}$ at 20,000 $\mathrm{g}$, and the supernatant containing the DNA was transferred to a new tube.

\section{Genotyping}

Val1016Ile genotypes from the mosquito $k d r$ mutation were determined based on the protocol described by Saavedra-Rodriguez et al. (2007) and Martins et al. (2009). Three primers were used: one that was specific for the wild allele (Val) (5'-GCG GGC AGG GCG GGG GCG GGG CCA CAA ATT GTT TCC CAC CCG CAC CGG-3'), one that was specific for the mutant allele (Ile) (5'-GCG 145 GGC ACA ATT GTT TCC CAC CCG CAC TGA-3'), and one that was common to both (forward) (5'-GGA TGA ACC GAA ATT GGA CAA AAG C-3'). A polymerase chain reaction was performed in a final volume of $20 \mu \mathrm{L}$ that contained $1.5 \mathrm{mM} \mathrm{MgCl}_{2}$ (Ludwig Biotechnology, Porto Alegre, RS, Brazil), $1.0 \mathrm{mM}$ dNTP (Ludwig Biotechnology), 2.5 U Taq DNA polymerase (Ludwig Biotechnology), 1X Taq buffer, 1.0

Genetics and Molecular Research 15 (4): gmr15048940 
pmol forward primer, $0.5 \mathrm{pmol}$ of each of the Val and Ile primers, and $\sim 50 \mathrm{ng}$ DNA. The thermocycling conditions consisted of an initial denaturation at $95^{\circ} \mathrm{C}$ for $12 \mathrm{~min}$ and 39 cycles of denaturation at $95^{\circ} \mathrm{C}$ for $20 \mathrm{~s}$, annealing at $60^{\circ} \mathrm{C}$ for $1 \mathrm{~min}$, extension at $72^{\circ} \mathrm{C}$ for $30 \mathrm{~s}$, followed by a final extension at $72^{\circ} \mathrm{C}$ for $5 \mathrm{~min}$ and an increment from $65^{\circ}$ to $95^{\circ} \mathrm{C}$ at a rate of $0.3^{\circ} \mathrm{C} / \mathrm{s}$. To verify the amplified alleles, $12 \%$ polyacrylamide gel electrophoresis was performed with a 25-bp DNA ladder. The presence of a 98-bp single amplicon indicated a dominant homozygous individual (susceptible) (Val/Val); the presence of a 78-bp single amplicon indicated a recessive homozygous individual (mutant) (Ile/Ile); and the presence of two amplicons indicated a heterozygous individual (susceptible) (Val/Ile) (Figure 2).

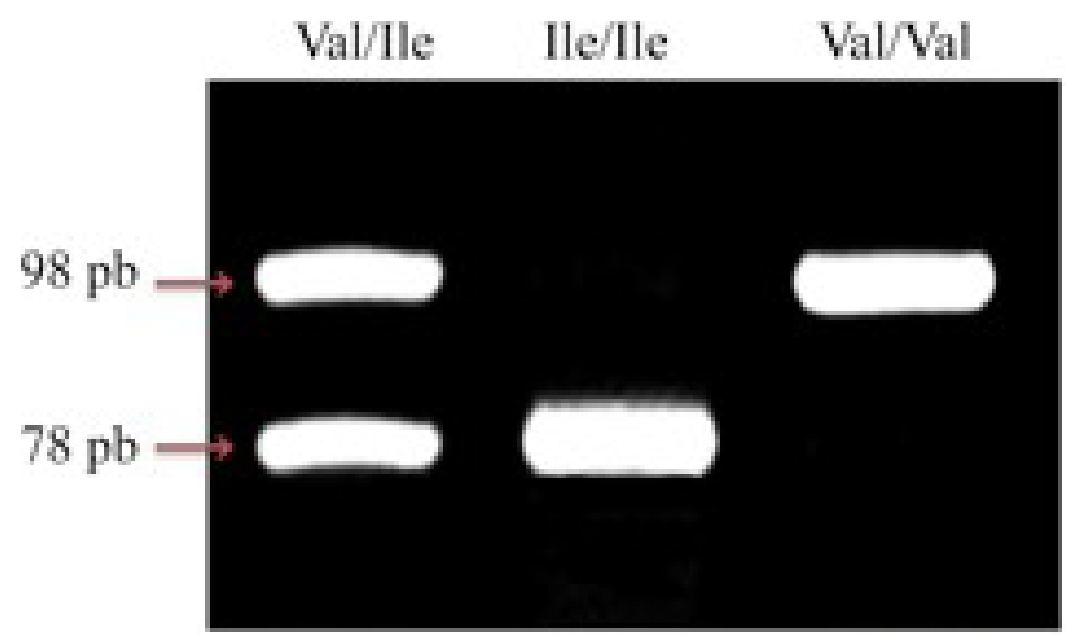

Figure 2. Representative profile with three amplifications of the 1016 site from the voltage-dependent sodium channel gene ( $\left.N a_{v}\right)$ of Aedes aegypti larvae and pupae from the west mesoregion of Santa Catarina, Brazil, according to Saavedra-Rodriguez et al. (2007). Val/Ile, heterozygote samples (Aa), 98 and 78 bp; Ile/Ile, resistant recessive homozygote (aa), $78 \mathrm{bp}$; and $\mathrm{Val} / \mathrm{Val}$, wild dominant homozygote (AA), $98 \mathrm{bp}$.

\section{Statistical analysis}

A comparison of the genotype and allele frequencies among the microregions was performed using the Pearson chi-square test, with a $\mathrm{P}<0.05$ significance level. The Arlequin 3.1 software was used to calculate the expected $\left(H_{\mathrm{E}}\right)$ and observed $\left(H_{\mathrm{O}}\right)$ heterozygosities and the Hardy-Weinberg equilibrium (HWE) (Excoffier and Lischer, 2010).

\section{RESULTS and DISCUSSION}

Of the 349 A. aegypti specimens evaluated, 109 (31.0\%) were homozygous for Val, 138 (40.0\%) were homozygous for Ile, and 102 (29.0\%) were heterozygous for Val/ Ile (Figure 3). Therefore, almost $40 \%$ of the individuals analyzed had the $k d r$ mutation that may confer pyrethroid resistance (Saavedra-Rodriguez et al., 2007; Davies et al., 2008). The highest frequency of Ile/Ile homozygote genotypes was in the Joaçaba microregion (Figure 3). 


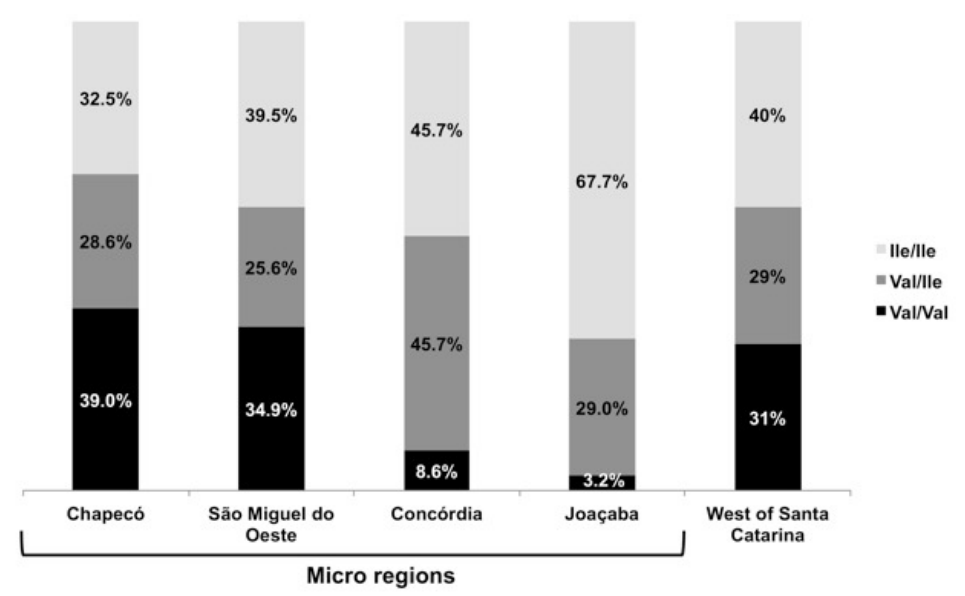

Figure 3. Genotype frequencies of genotypes of the Val1016Ile mutation in the voltage-dependent sodium channel gene $\left(N a_{v}\right)$ in the west mesoregion of Santa Catarina and in each microregion. Differences observed among the genotypes in each microregion were statistically significant (chi-square $=29.4$; d.f. $=6 ; \mathrm{P}<0.0001$ ).

Phenotypes that are resistant to insecticides are only manifested in individuals that are in recessive homozygosis (Ile/Ile) (Saavedra-Rodriguez et al., 2007; Davies et al., 2008). An increase in the frequency of mutation 1016Ile in $k d r$ has been reported previously in the Americas (Rodríguez et al., 2005; García et al., 2009; Alvarez et al., 2015); in the Brazilian northeast, only heterozygous individuals possess the mutation (Martins et al., 2009; Lima et al., 2011). Heterozygous individuals have been observed by Alvarez et al. (2015) in Venezuela. Batista (2012) noted that in some cities in São Paulo State, Brazil, the genotype frequency of homozygous Ile was 78\%. Considering only southern Brazil, Piccoli (2010) also observed the presence of Ile/Ile homozygous individuals in western cities of Parana State. Frequencies of mosquitoes with the resistant genotype (Ile/Ile) were similar in the west of Santa Catarina and in other Brazilian regions.

The observed frequencies of wild-type (Val) and mutant (Ile) alleles in the west mesoregion of Santa Catarina were 0.455 and 0.545 , respectively (Table 1). Joaçaba and Concórdia had significantly higher mutant allele frequencies ( 0.825 and 0.685 , respectively) than the other microregions $(\mathrm{P}=0.0005)$. The high frequency of this allele may be due to the fewer mosquito foci identified by DIVE/SC during the period of the study in Joaçaba $(\mathrm{N}=18)$ and Concórdia $(\mathrm{N}=20)$ than in São Miguel do Oeste $(\mathrm{N}=432)$ or Chapecó $(\mathrm{N}=1613)$ (DIVE, 2015). Studies performed in other Brazilian regions have reported different frequencies of Ile, which vary between 0.22 and 0.78 in natural populations (Martins et al., 2009; Piccoli, 2010; Lima et al., 2011; Batista, 2012). However, even with a high frequency of Ile, the Joaçaba and Concórdia populations remain in HWE (Table 1), which suggests that selection pressure is not occurring in these regions, but these populations should be monitored for an increase in pyrethroid-resistant mosquitoes if control measures are introduced.

In contrast to the Joaçaba and Concórdia populations, the São Miguel do Oeste and Chapecó samples were not in HWE (chi-square $>27$; d.f. $=1$; $\mathrm{P}<0.0001$ ) (Table 1). The HWE deviation observed in these two populations may have been caused by a possible initial founder effect, when small $A$. aegypti populations from other regions started appearing, bringing Ile with them. Such a hypothesis is reasonable, because heavy road transport flows 
Table 1. Genotype constitution and descriptive statistics of the $k d r$ gene in several samples from Santa Catarina State, Brazil.

\begin{tabular}{l|c|c|c|c|c|c|c|c|c}
\hline Population & $\mathrm{N}$ & $\mathrm{Val} /$ Val & Val/Ile & Ile/Ile & Val & Ile $(k d r)$ & Hardy-Weinberg & $H_{\mathrm{O}}$ & $H_{\mathrm{E}}$ \\
\hline São Miguel do Oeste & 129 & 45 & 33 & 51 & 0.475 & 0.525 & $30.63^{* *}$ & 0.256 & 0.500 \\
\hline Chapecó & 154 & 60 & 44 & 50 & 0.535 & 0.465 & $27.97^{* *}$ & 0.286 & 0.499 \\
\hline Concórdia & 35 & 03 & 16 & 16 & 0.315 & $0.685^{*}$ & 0.13 & 0.457 & 0.437 \\
\hline Joaçaba & 31 & 01 & 09 & 21 & 0.175 & $0.825^{*}$ & 0.00 & 0.290 & 0.297 \\
\hline Total West & 349 & 109 & 102 & 138 & 0.455 & 0.545 & $59.07^{* *}$ & 0.292 & 0.497 \\
\hline
\end{tabular}

$\mathrm{N}$, total number of mosquitoes per sample; $H_{\mathrm{E}}$, expected heterozygosity; $H_{\mathrm{O}}$, observed heterozygosity; Val, frequency of the Val allele; Ile, frequency of the Ile allele. ${ }^{*} \mathrm{P}<0.05, * * \mathrm{P}<0.0001$.

into the west of Santa Catarina from different regions of the country, particularly from regions with a high number of mosquito foci. In these regions, such as the Southeast and Central-West, the presence of the Ile mutation has been confirmed (Martins et al., 2009; Brito et al., 2013; Aguirre-Obando et al., 2016). In addition, the Southeast and Central-West regions have a direct influence on the dispersion of these mosquitoes to other regions (Julio et al., 2009). For this reason, the west region of Santa Catarina is considered an emerging region for arbovirus diseases transmitted by $A$. aegypti, with significant increases in the number of cases and vector foci in recent years (DIVE, 2015). A founder effect has also been observed in A. gambiae (Santolamazza et al., 2015) and Aedes albopictus (Maia et al., 2009).

Despite the fitness cost that the Ile mutation confers to the vector (Brito et al., 2013), the frequency of this allele may have increased after a probable founder effect in these two very small populations. This initially occurred due to the effects of genetic drift (Nei, 1975; Ohta and Gillespie, 1996), and subsequently or simultaneously occurred due to selection pressure, because from mid-2014 to mid-2015, alpha-cypermethrin, a pyrethroid compound, was used in strategic points in the cities of Chapecó and São Miguel do Oeste (Nascimento JC, personal communication). Domestic insecticides used by the general population may also contain pyrethroids, and these could be an important selection pressure (Aguirre-Obando et al., 2016).

The $H_{\mathrm{O}}$ values were much lower than the $H_{\mathrm{E}}$ values, indicating a depletion of heterozygotes and consequently high endogamy, which causes an increase in the number of homozygotes to the detriment of heterozygote numbers (Charlesworth, 2009). Therefore, considering the initial founder effect and a secondary selection pressure on these two populations, it is possible that the HWE deviation was caused by relatively high levels of endogamy and an excess of homozygotes.

Resistance results from an accelerated evolutionary process in which the mosquito population is under intense selection pressure, resulting in the survival of individuals that possess resistance alleles. Pyrethroids are a selection pressure, and their continuous use may select resistant individuals for survival (Braga and Valle, 2007b). Studies that have exposed larvae to synthetic insecticides have reported that the selection pressure on the larvae promotes the selection of resistant individuals, increasing the frequency of resistant mosquitoes after exposure (Carvalho et al., 2004). The identification of these mutations in the field compromises the use of pyrethroids for mosquito control (Saavedra-Rodriguez et al., 2007). The observed frequency of Ile/Ile homozygous individuals in the west of Santa Catarina State is concerning, because the implementation of synthetic insecticides as a control measure may increase the frequency of this allele through the selection of resistant populations (Braga and Valle, 2007a; Aguirre-Obando et al., 2016). However, the Ile/Ile genotype carries a fitness cost (Brito et

Genetics and Molecular Research 15 (4): gmr15048940 
al., 2013), meaning that the wild allele would rapidly increase in frequency in the absence of insecticides (Belinato et al., 2012).

Therefore, the continuous monitoring for resistance in these populations is recommended (Braga and Valle, 2007b; Piccoli, 2010; Lima et al., 2011; Aguirre-Obando et al., 2016), not only for the mutation Val1016Ile, but also for other mutations that are related to resistance to different synthetic insecticides. It will then be possible to implement different mosquito control strategies, such as different insecticides (Braga and Valle, 2007a), biological insecticides such as Bacillus thuringiensis serotype israelensis (Bti) (Polanczyk et al., 2003) or others (Lima et al., 2015), genetically modified mosquitoes (Carvalho et al., 2015), or mosquitoes infected with the Wolbachia endosymbiont (Almeida et al., 2011).

\section{CONCLUSIONS}

This study evaluated the presence and frequency of the $k d r$ mutation, Val1016Ile, in A. aegypti from the west mesoregion of Santa Catarina, Brazil. The results obtained indicate a high frequency of mosquitoes with a genotype resistant to pyrethroids (Ile/Ile), a pattern similar to other Brazilian regions. A HWE deviation in these mosquito populations may have occurred due to founder effects, elevated endogamy within the populations, and the use of alpha-cypermethrin in some municipalities of the region. The resistant phenotype, as measured by larval bioassay, was not investigated in these populations; however, previous studies have shown that Ile is related to pyrethroid insecticide resistance. Therefore, these populations should be continuously monitored for resistance to insecticides used in A. aegypti control. Our study highlights the need for alternative methods that do not involve the use of synthetic insecticides to control this vector.

\section{Conflicts of interest}

The authors declare no conflicts of interest.

\section{ACKNOWLEDGMENTS}

We are thankful to Andre Nóbrega Pitaluga for assistance. M.L. Colleta, C. Frizzoa, and E. Orlandina received scholarships from Universidade do Oeste de Santa Catarina (Unoesc) and CNPq (Brazilian Government Agency).

\section{REFERENCES}

Aguirre-Obando AO, Pietrobon AJ, Dalla Bona AC and Navarro-Silva MA (2016). Contrasting patterns of insecticide resistance and knockdown resistance (kdr) in Aedes aegypti populations from Jacarezinho (Brazil) after a dengue outbreak. Rev. Bras. Entomol. 60: 94-100 http://dx.doi.org/10.1016/j.rbe.2015.11.009.

Almeida FD, Moura AS, Cardoso AF, Winter CE, et al. (2011). Effects of Wolbachia on fitness of Culex quinquefasciatus (Diptera; Culicidae). Infect. Genet. Evol. 11: 2138-2143 http://dx.doi.org/10.1016/j.meegid.2011.08.022.

Alvarez LC, Ponce G, Saavedra-Rodriguez K, Lopez B, et al. (2015). Frequency of V1016I and F1534C mutations in the voltage-gated sodium channel gene in Aedes aegypti in Venezuela. Pest Manag. Sci. 71: 863-869 http://dx.doi. org $10.1002 /$ ps.3846.

Batista E (2012). Evolução de mutações no gene do canal de sódio associadas à resistência tipo Kdr em populações de Aedes (Stegomyia) aegypti do Estado de São Paulo. Master’s thesis, Faculdade de Saúde Pública, USP, São Paulo.

Genetics and Molecular Research 15 (4): gmr15048940 
Belinato TA, Martins AJ and Valle D (2012). Fitness evaluation of two Brazilian Aedes aegypti field populations with distinct levels of resistance to the organophosphate temephos. Mem. Inst. Oswaldo Cruz 107: 916-922 http://dx.doi. org/10.1590/S0074-02762012000700013.

Braga IA and Valle D (2007a). Aedes aegypti: inseticidas, mecanismos de ação e resistência. Epidemiol. Serv. Saúde 16: 279-293.

Braga IA and Valle D (2007b). Aedes aegypti: vigilância, monitoramento da resistência e alternativas de controle no Brasil. Epidemiol. Serv. Saúde 16: 205-302.

Brasil MS (2016). Monitoramento dos casos de dengue, febre de chikungunya e febre pelo vírus Zika até a Semana Epidemiológica 13, 2016. Boletim Epidemiológico. Available at [http://portalsaude.saude.gov.br/images/pdf/2016/ abril/26/2016-014---Dengue-SE13-prelo.pdf]. Accessed April 22, 2016.

Brengues C, Hawkes NJ, Chandre F, McCarroll L, et al. (2003). Pyrethroid and DDT cross-resistance in Aedes aegypti is correlated with novel mutations in the voltage-gated sodium channel gene. Med. Vet. Entomol. 17: 87-94 http:// dx.doi.org/10.1046/j.1365-2915.2003.00412.x.

Brito LP, Linss JGB, Lima-Camara TN, Belinato TA, et al. (2013). Assessing the effects of Aedes aegypti kdr mutations on pyrethroid resistance and its fitness cost. PLoS One 8: e60878 http://dx.doi.org/10.1371/journal.pone.0060878.

Carvalho DO, McKemey AR, Garziera L, Lacroix R, et al. (2015). Suppression of a field population of Aedes aegypti in Brazil by sustained release of transgenic male mosquitoes. PLoS Negl. Trop. Dis. 9: e0003864 http://dx.doi. org/10.1371/journal.pntd.0003864.

Carvalho MdoS, Caldas ED, Degallier N, Vilarinhos PdeT, et al. (2004). Suscetibilidade de larvas de Aedes aegypti ao inseticida temefós no Distrito Federal. Rev. Saude Publica 38: 623-629 http://dx.doi.org/10.1590/S003489102004000500002.

Charlesworth B (2009). Fundamental concepts in genetics: effective population size and patterns of molecular evolution and variation. Nat. Rev. Genet. 10: 195-205 http://dx.doi.org/doi:10.1038/nrg2526. http://dx.doi.org/10.1038/ $\underline{\operatorname{nrg} 2526}$

Chediak M, G Pimenta Jr F, Coelho GE, Braga IA, et al. (2016). Spatial and temporal country-wide survey of temephos resistance in Brazilian populations of Aedes aegypti. Mem. Inst. Oswaldo Cruz 111: 311-321 http://dx.doi. org/10.1590/0074-02760150409.

Davies TE, O'Reilly AO, Field LM, Wallace B, et al. (2008). Knockdown resistance to DDT and pyrethroids: from targetsite mutations to molecular modelling. Pest Manag. Sci. 64: 1126-1130 http://dx.doi.org/10.1002/ps.1617.

DIVE (2015). Boletim sobre situação da dengue, febre de chikungunya e febre do zika vírus em Santa Catarina. Diretoria de Vigilância Epidêmiológica do Estado de Santa Catarina, Brasil. Available at [http://www.dive.sc.gov.br/index. php/arquivo-noticias/250-boletim-sobre-situacao-da-dengue-febre-de-chikungunya-e-febre-do-zika-virus-em-santacatarina-atualizado-em-06-01-2016]. Accessed January 15, 2016.

Excoffier L and Lischer HEL (2010). Arlequin suite ver 3.5: a new series of programs to perform population genetics analyses under Linux and Windows. Mol. Ecol. Resour. 10: 564-567 http://dx.doi.org/10.1111/j.1755-0998.2010.02847.x.

FUNASA (2001). Dengue instruções para pessoal de combate ao vetor: manual de normas técnicas. Fundação Nacional da Saúde, Brasil. Available at [http://bvsms.saude.gov.br/bvs/publicacoes/funasa/man_dengue.pdf]. Accessed March 15, 2016.

García GP, Flores AE, Fernández-Salas I, Saavedra-Rodríguez K, et al. (2009). Recent rapid rise of a permethrin knock down resistance allele in Aedes aegypti in México. PLoS Negl. Trop. Dis. 3: e531 http://dx.doi.org/10.1371/journal. pntd.0000531.

Honório NA, Câmara DCP, Calvet GA and Brasil P (2015). Chikungunya: an arbovirus infection in the process of establishment and expansion in Brazil. Cad. Saude Publica 31: 906-908 10.1590/0102-311XPE020515.

Ishak IH, Jaal Z, Ranson H and Wondji CS (2015). Contrasting patterns of insecticide resistance and knockdown resistance (kdr) in the dengue vectors Aedes aegypti and Aedes albopictus from Malaysia. Parasit. Vectors 8: 181 http://dx.doi. org/10.1186/s13071-015-0797-2.

Julio NB, Chiappero MB, Rossi HJ, Rondan Dueñas JC, et al. (2009). Genetic structure of Aedes aegypti in the city of Córdoba (Argentina), a recently reinfested area. Mem. Inst. Oswaldo Cruz 104: 626-631 http://dx.doi.org/10.1590/ $\underline{\text { S0074-02762009000400016. }}$.

Lima EP, Paiva MHS, de Araújo AP, da Silva EV, et al. (2011). Insecticide resistance in Aedes aegypti populations from Ceará, Brazil. Parasit. Vectors 4: 5 http://dx.doi.org/10.1186/1756-3305-4-5.

Lima VS, Pinto AC and Rafael MS (2015). Effect of isodillapiole on the expression of the insecticide resistance genes GSTE7 and CYP6N12 in Aedes aegypti from central Amazonia. Genet. Mol. Res. 14: 16728-16735 http://dx.doi. org/10.4238/2015.December.11.20.

Lopes N, Nozawa C and Linhares REC (2014). General features and epidemiology of emerging arboviruses in Brazil. Rev. Pan-Amaz. Saude. 5: 55-64 10.5123/S2176-62232014000300007.

Genetics and Molecular Research 15 (4): gmr15048940 
Macoris MdeL, Andrighetti MTM, Wanderley DMV and Ribolla PEM (2014). Impact of insecticide resistance on the field control of Aedes aegypti in the State of São Paulo. Rev. Soc. Bras. Med. Trop. 47: 573-578 http://dx.doi. org/10.1590/0037-8682-0141-2014.

Maia RT, Scarpassa VM, Maciel-Litaiff LH and Tadei WP (2009). Reduced levels of genetic variation in Aedes albopictus (Diptera: Culicidae) from Manaus, Amazonas State, Brazil, based on analysis of the mitochondrial DNA ND5 gene. Genet. Mol. Res. 8: 998-1007 http://dx.doi.org/10.4238/vol8-3gmr624.

Marcondes CB and Ximenes MFFM (2015). Zika virus in Brazil and the danger of infestation by Aedes (Stegomyia) mosquitoes. Rev. Soc. Bras. Med. Trop. 10.1590/0037-8682-0220-2015.

Martinez-Torres D, Chandre F, Williamson MS, Darriet F, et al. (1998). Molecular characterization of pyrethroid knockdown resistance (kdr) in the major malaria vector Anopheles gambiae s.s. Insect Mol. Biol. 7: 179-184 http:// dx.doi.org/10.1046/j.1365-2583.1998.72062.x.

Martinez-Torres D, Chevillon C, Brun-Barale A and Pauron D (1999). Voltage-dependent Na+ channels in pyrethroidresistant Culex pipiens L. mosquitoes. Pest Manag. Sci. 55: 1012-1020 http://dx.doi.org/10.1002/(SICI)10969063(199910)55:10<1012::AID-PS39>3.0.CO;2-5.

Martins AJ, Lima JBP, Peixoto AA and Valle D (2009). Frequency of Val1016lle mutation in the voltage-gated sodium channel gene of Aedes aegypti Brazilian populations. Trop. Med. Int. Health 14: 1351-1355 http://dx.doi.org/10.1111/ j.1365-3156.2009.02378.x.

Nei M (1975). Molecular population genetics and evolution. North-Holland Pub. Co., Amsterdam.

Ohta T and Gillespie JH (1996). Development of neutral and nearly neutral theories. Theor. Popul. Biol. 49: 128-142. http://dx.doi.org/10.1006/tpbi.1996.0007

Piccoli CF (2010). Análise de mutações no fragmento do gene que expressa a proteína transmembrana de canal de sódio $(k d r)$ e da suscetibilidade a inseticidas em populações de Aedes (Stegomyia) aegypti (Linnaeus, 1762) (Diptera: Culicidae). Master's thesis, UFPR, Paraná.

Polanczyk RA, Garcia MO and Alves SB (2003). Potencial de Bacillus thuringiensis israelensis Berliner no controle de Aedes aegypti. Rev. Saúde Púb 37: 813-816 10.1590/S0034-89102003000600020.

Rajatileka S, Black WC, 4th, Saavedra-Rodriguez K, Trongtokit Y, et al. (2008). Development and application of a simple colorimetric assay reveals widespread distribution of sodium channel mutations in Thai populations of Aedes aegypti. Acta Trop. 108: 54-57 http://dx.doi.org/10.1016/j.actatropica.2008.08.004.

Rodríguez MM, Bisset JA, De Armas Y and Ramos F (2005). Pyrethroid insecticide-resistant strain of Aedes aegypti from Cuba induced by deltamethrin selection. J. Am. Mosq. Control Assoc. 21: 437-445 http://dx.doi.org/10.2987/8756971X(2006)21[437:PISOAA]2.0.CO;2.

Saavedra-Rodriguez K, Urdaneta-Marquez L, Rajatileka S, Moulton M, et al. (2007). A mutation in the voltage-gated sodium channel gene associated with pyrethroid resistance in Latin American Aedes aegypti. Insect Mol. Biol. 16: 785-798 http://dx.doi.org/10.1111/j.1365-2583.2007.00774.x.

Santolamazza F, Caputo B, Nwakanma DC, Fanello C, et al. (2015). Remarkable diversity of intron-1 of the para voltagegated sodium channel gene in an Anopheles gambiae/Anopheles coluzzii hybrid zone. Malar. J. 14: 9 http://dx.doi. org/10.1186/s12936-014-0522-1.

Villar L, Dayan GH, Arredondo-García JL, Rivera DM, et al.; CYD15 Study Group (2015). Efficacy of a tetravalent dengue vaccine in children in Latin America. $N$. Engl. J. Med. 372: 113-123 http://dx.doi.org/10.1056/NEJMoa1411037.

Genetics and Molecular Research 15 (4): gmr15048940 